\title{
Isotopic evidence for episodic mantle melting in the Hadean
}

\author{
ALESSANDRO MALTESE ${ }^{1,2}$, GUILLAUME CARO ${ }^{1}$, OM \\ PRAKASH PANDEY ${ }^{3}$, DEWASHISH UPADHYAY ${ }^{4}$ AND \\ KLAUS MEZGER ${ }^{2}$ \\ ${ }^{1}$ Université de Lorraine, CNRS, CRPG \\ ${ }^{2}$ University of Bern \\ ${ }^{3}$ Indian Institute of Technology Kanpur \\ ${ }^{4}$ Indian Institute of Technology, Kharagpur \\ Presenting Author: alessandro.maltese@geo.unibe.ch
}

The scarcity or absence of ancient material in the exposed rock record is a major hindrance in constraining the early silicate differentiation of the Earth, between 4.5 and 3.8 Ga. It also limits the reconstruction of Earth's early geodynamic evolution, which, is primarily inferred from numerical modelling. However, using extinct radioisotope systems such as the ${ }^{146} \mathrm{Sm}_{-}{ }^{142} \mathrm{Nd}$ chronometer, it is possible to constrain early Earth processes even in the absence of a physical rock record. Using this approach, remnants of Hadean crustal and depleted mantle components have been identified in rocks from some of the oldest cratons ${ }^{[1,2]}$. The majority of these ancient components preserve a record of a single crust-mantle differentiation event at 4.4 $\mathrm{Ga}^{[3]}$. Apart from this event, little is known about the evolution of the Hadean crust-mantle system.

Here we present coupled ${ }^{146,147} \mathrm{Sm}-{ }^{142,143} \mathrm{Nd}$ isotope systematics of chemically diverse rocks from the wellcharacterized Paleoarchean Bastar and Singhbhum cratons in central and eastern India ${ }^{[4-6]}$. A comparison of tonalitetrondhjemite-granodiorites (TTGs) from the two terranes reveals no ${ }^{142} \mathrm{Nd}$ anomalies in the Bastar Craton, while TTGs from the Singhbhum Craton define a trend in $\mu^{142} \mathrm{Nd}$ vs $\varepsilon^{143} \mathrm{Nd}$ isotope space that extends from the primitive mantle composition up to $\mu^{142} \mathrm{Nd} \approx+6 \mathrm{ppm}$ and $\varepsilon^{143} \mathrm{Nd}=+5$ ( $\pm 2.5 \mathrm{ppm}, 2$ S.D. $)$.

Despite the near-synchronous formation of the Paleoarchean TTG crust in the two cratons, between ca. 3.5 and $3.3 \mathrm{Ga}$, these results demonstrate that their protoliths sampled distinct reservoirs, indicating heterogeneity of the Archean mantle. The investigated samples from the Singhbhum Craton derived from a mantle reservoir that first differentiated in a so-far undocumented event at $4.19 \mathrm{Ga}$. This discrete record of crust-mantle differentiation is mirrored in the Hf isotopic evolution of $>4 \mathrm{Ga}$ zircon, suggesting that mantle differentiation in the Hadean proceeded in large-scale, possibly global pulses of increased magmatic activity and crustal rejuvenation.

References: [1] Caro et al. (2003), Nature 423, 428-432. [2] O'Neil, et al. (2008), Science 321, 1828-1831. [3] Morino et al. (2017), EPSL 463, 136-150. [4] Maltese et al. (2019), Goldschmidt Conference. [5] Upadhyay et al. (2014), Precambrian Res. 252, 180-190. [6] Pandey et al. (2019), Chem. Geol. 512, 85-106. 